\title{
Relato de Pesquisa: "Procedimentos Analíticos e Princípios Filosóficos - uma Avaliação Crítica da Obra de Heinrich Schenker”
}

Guilherme Sauerbronn de Barros

(PPGMUS-UDESC)

Iniciado em agosto de 2006, o Projeto de Pesquisa "Procedimentos Analíticos e Princípios Filosóficos - uma avaliação crítica da obra de Heinrich Schenker” surgiu do interesse comum dos pesquisadores Guilherme Sauerbronn de Barros (UDESC) e Cristina Capparelli Gerling (UFRGS) pela análise schenkeriana. A escassez de trabalhos em língua portuguesa sobre este tema foi um incentivo a mais, uma vez que a própria área da análise musical encontra-se em fase de consolidação em nosso país.

Um dos problemas mais comuns no estudo da obra de Schenker é a interpretação de sua teoria como mecânica do processo de "redução", ficando de lado suas considerações metafísicas, tão fundamentais para sua visão de mundo e de música. O próprio Schenker pareceu antever o destino de sua obra ao escolher como epígrafe de um de seus textos a seguinte passagem de Kant: "Neste caso, o risco não é ser desaprovado, mas não ser compreendido"1. A apreensão de Schenker encontra respaldo na constatação de Nicholas Cook de que "os expoentes americanos da análise schenkeriana preferiram ignorar os fundamentos psicológicos e metafísicos de suas teorias"

De fato, o estudo da obra de Schenker não é tarefa simples, pois coloca para o estudioso uma série de desafios de ordem técnica e conceitual. Em primeiro lugar, é necessário ter consciência da importância do contraponto como preparação para a análise. Além disso, é importante compreender que Schenker considerava a si próprio um "filósofo" da música: para ele, a descoberta da "estrutura fundamental" (Ursatz) é verdadeira revelação em sentido místico, e as leis que ela expressa são as mesmas que regem o cosmos e a vida humana. A síntese final alcançada por Schenker, reunião de suas convicções

\footnotetext{
${ }^{1}$ KANT apud SCHENKER, Heinrich. The Masterwork in Music, 3 v., New York: Cambridge University Press, 1994, p.1

${ }^{2}$ COOK, Nicholas. A Guide to Musical Analysis, New York: Oxford University Press, 1987, p.27
} 
musicais e filosóficas, é o próprio processo de "redução", que estabelece a ligação entre a "composição livre" (Freie Satz) e a "estrutura fundamental".

O projeto deveria, portanto, cobrir estes dois aspectos essenciais do pensamento schenkeriano: o estudo do contraponto como base para os processos reducionais da análise; a investigação dos conceitos fundamentais da teoria schenkeriana, tendo como referência a filosofia alemã do final do XVIII e início do XIX.

O primeiro resultado concreto da pesquisa foi o capítulo de livro intitulado "Análise Schenkeriana, Interpretação e Crítica", parte de um amplo projeto editorial sobre a Pesquisa em Música no Brasil. Levando em conta as dificuldades que envolvem uma publicação deste tipo, torna-se compreensível o atraso na publicação, cujo prazo original fora previsto para 2007, mas que, até o momento, não se efetivou.

No mesmo ano de 2007 foram publicados dois artigos referentes a esta pesquisa. "O Conceito Schenkeriano de 'Organicidade' e a Sonata K533 de Mozart” foi apresentado na III Jornada de Pesquisa e XVII Seminário de Iniciação Científica da UDESC e publicado nos anais do evento (ISSN 1808-3129). Neste artigo analisamos o conceito de organicidade, um dos pontos-chave do pensamento de Schenker, à luz de dois textos deste autor, "A Organicidade na Forma Sonata" (Vom Organischen der Sonatenform) e "A Natureza Orgânica da Fuga como Demonstrado na Fuga em Dó menor do Cravo Bem Temperado de J.S. Bach, livro I" (Das Organische der Fuge aufgezeigt an der I. C-MollFugeaus dem Wohltemperierten Klavier von Joh. Seb. Bach), ambos editados no segundo volume do anuário Das Meisterwerk in der Musik, de 1926. Schenker reconhece, tanto na Sonata clássica como na Fuga barroca, um mesmo e único princípio - a organicidade como elemento gerador da forma. Corroborando esta percepção, a análise do contexto histórico em torno da composição da sonata K533 de Mozart reforça a relação entre o alto classicismo vienense e a formação contrapontística de um de seus mais notáveis expoentes.

Em "O Intérprete Schenkeriano e o Conceito de Organicidade", apresentado no SIMPEMUS 4 - Simpósio de Pesquisa em Música 2007, promovido pela Universidade Federal do Paraná UFPR e publicado nos anais do evento (ISBN 078-85-98826-13-4), procuramos definir conceitualmente o "intérprete schenkeriano" e verificar quais as implicações do conceito de coerência orgânica para a interpretação de obras musicais. Ao final do artigo, realizamos uma análise schenkeriana do prelúdio BWV 927 de J. S. Bach, 
procurando relacionar aspectos formais revelados pela análise com as escolhas interpretativas que se colocam para o intérprete.

No ano de 2008 tivemos mais dois artigos publicados. O primeiro deles, na revista Opus, volume 13, número 2, com data de dezembro de 2007 (ISSN 0103-7412), editada pela ANPPOM, Associação Nacional de Pesquisa e Pós-Graduação em Música. O artigo trata mais uma vez da fecunda relação entre análise schenkeriana e performance. Após rever um projeto esboçado por Heinrich Schenker, Die Kunst des Vortrags, no qual são discutidas estratégias interpretativas designadas por "dissimulação" e "emolduração", ambas com referência aos níveis hierárquicos da estrutura musical, oferecemos uma análise que abrange não apenas um ponto de vista composicional, mas procura resgatar o efeito instrumental. Esta abordagem analítica do primeiro movimento da sonata K 533-494 de W. A. Mozart visa demonstrar que análise e interpretação são, para Schenker, manifestações afins e complementares de uma concepção musical orgânica.

Paralelamente, duas disciplinas do mestrado em música, ministradas pelo professor Guilherme Sauerbronn de Barros no PPGMUS da UDESC, tiveram seus planos de ensino baseados na bibliografia e nos resultados desta pesquisa. Foram elas Análise I e Análise II. Na disciplina Análise I (2007-1 e 2008-1) foi trabalhado conteúdo relativo à análise schenkeriana; já a disciplina Análise II (2007-1) teve como objeto a análise de música póstonal, baseada na chamada "teoria dos conjuntos de classes de alturas" ou pitch class analysis. Esta teoria foi desenvolvida por teóricos (Milton Babbit, Allen Forte) que se enquadram no grupo dos chamados "pós-schenkerianos", estudiosos que têm no pensamento de Schenker (e também de outros teóricos, como por exemplo Rudolph Réti e Arnold Schoenberg) uma base conceitual para elaborar suas próprias teorias. Atualmente, a disciplina Análise II (2008-2) combina diferentes técnicas analíticas no estudo de obras do repertório erudito brasileiro.

Foi a partir desse desdobramento da pesquisa em direção à "teoria dos conjuntos de classes de altura" que se originou o artigo "O Dodecafonismo na Sonata 1 de Penalva". Escrito em parceria com o mestrando do PPGMUS Alexandre Gonçalves, o artigo procura construir uma concepção analítico-interpretativa que aproxime as soluções instrumentais e as características estruturais da obra, a partir da aplicação da teoria dos conjuntos e do estudo da peça ao piano. Ficou claro, através deste estudo, que, assim como a análise 
schenkeriana tem importantes implicações para a interpretação de obras tonais, a análise segundo a teoria dos conjuntos se mostrou um valioso auxiliar na identificação de elementos estruturais em obras pós-tonais, verdadeiro guia para o intérprete na compreensão da obra. O trabalho foi apresentado no XVIII Congresso da Anppom e será publicado nos anais do evento.

Apesar do cumprimento das etapas previstas no projeto original, a pesquisa está longe de terminar. $\mathrm{O}$ assunto é vasto e a bibliografia foi significativamente ampliada ao longo do período de vigência do projeto. No período de prorrogação da pesquisa, entre agosto de 2008 e julho de 2010 , estão previstas as seguintes atividades:

- aplicação das técnicas e princípios da análise schenkeriana a repertório brasileiro, com a finalidade de produzir artigo(s) sobre o assunto.

- Aprofundamento do estudo das obras dos "continuadores" de Schenker, a saber, Felix Salzer, Allen Forte, A. Cadwallader etc.

- Aplicação da "teoria dos conjuntos" ao repertório atonal ou dodecafônico brasileiro.

Em linhas gerais, portanto, o que se está propondo é uma aproximação dos conteúdos já trabalhados na primeira etapa da pesquisa e o repertório - tonal e atonal nacional. 